\title{
Last hurdle cleared before US-French AIDS accord
}

\section{- New foundation from royalties of AIDS test - US-French interests agree draft settlement}

Washington \& London

ThE details of a final settlement to the US-French dispute over the patent rights to a diagnostic test for AIDS (acquired immune deficiency syndrome) have been drafted by the two interested parties and could spawn an international research foundation devoted to the disease. Onc of the last obstacles to agreement was Icmoved on Sunday, 22 March, during a two-hour meeting at the Intercontinental Hotel in Frankfurt, between Dr Robert Gallo from the US National Cancer Institute and Professor Luc Montagnier of the Pasteur Institute in Paris.

The final version of the agreement is now expected to be signed during the visit by the prime minister of France, $M$ Jacques Chirac, to the United States on 29 March. Chirac is due to visit President Ronald Reagan at the White House. The French minister of health, Michell Barzach, is in Washington this week for a conference on AIDS

Gallo and Montagnicr have both applied for patents in the United States for the use of antibodies as a basis for testing for infection by human immunodeliciency virus (HIV). This is essentially the lest now widely used for assessing the infectious state of people and for deciding whether blood given for transfusion is contaminated

The French patent was applied for in December 1983. Four months later, the Gallo patent was applicd for and was swiftly granted by the US Patent Office, and the then US Secretary of Health and Human Services, Mrs Margaret Heckler, called a news conference to announce a decisive step forward in the then new battle against AIDS. Her enthusiasm added insult to the injury of the neglected French patent application.

The award of the Gallo patent was soon challenged by the Pasteur Institute in what is known technically as an 'interference", the appeals procedure provided by the US Patent Office. The judicial hearings that would normally long since have followed have been postponed on several occasions in the bclicf that the parties could reach an amicable scttlement.

Also in dispute has been the use made by Gallo of a virus isolate provided by Montagnier in September 1983. In accepting this isolate, Gallo and his associates agreed to use it for investigative purposes only, but the French have maintained that the NCI team used the material in the development of its own blood test.

Under the draft agreement, royalties from the use of HIV antibody tests for AIDS infection will be divided three ways, with one-third of the income going to each of the US Public Health Service (which, through the National Institutes of Health, is ultimately responsible for the National Cancer Institute) and the Pasteur Institute. The remaining third of the income will be directed towards a new international foundation, yet to bc established, for the support of AIDS research and treatment, especially in Africa.

At the request of the US parties to the draft agreement, a precondition for the settlement of the dispute has been that there should be an historical statement of the contributions of US and French groups to the discovery and characterization of the AIDS virus. This historica summary takes the form of a chronology going back to the characterization of the virus known as HTLV-I, which is responsible for the adult T-cell leukaemia endemic in soutbern Japan.

The final form of this document, negotiated in Frankfurt only last Sunday, is believed to include a preamble noting that collaboration between the Gallo and Montagnicr groups has never come to a halt, and promising continuing collaboration for the futurc. An earlier narrative account of the history of research on the AIDS virus was at the outset commis. sioned from Dr Jonas Salk, but has been replaced by a much more laconic statement. Nature hopes to publish the final vcrsion of the chronology next week.

The importance attached to this chronology, at least so far as the US side is concerned, is a measure of the degree to which the dispute has been dramatized and even personalized by articles appearing the popular press, both in France and in English-speaking countrics. The letter appearing elsewhere in this issue (p. 326), signed mostly by Nobel prizewinners, scems intended to sanitize this issue.

The main substance of the draft agreement will deal with the apportionment of patent royalties from the application of the antibody tests as they are used at present. The financial importance of the arrangement, and thus the potential of the proposed foundation to make a substantial impact on the problem of AIDS in Africa or elsewhere, will depend on the patents generating income for some substantial time.

\section{Dispute over plutonium in West Germany} Munich

A row has broken out between the West German government and the state of Hesse over the handling of plutonium by the nuclear industry. The Hesse government is refusing to enact a directive from German environment minister Walter Walkmann (Christian Democrat) under which the nuclear fuel manufacturer Alkem would be allowed to process up to 2.5 tonnes of plutonium at a time.

Hesse has instead brought suit in the German Supreme Court at Karlsruho challenging the federal government's jurisdiction over the plutonium industry. Wallmann is also reported to be considering a counter-suit.

Alkem, based at the city of Hanau, obtains both uranium and plutonium from reprocessing facilities in France, Britain and West Germany and prepares fuel for light-water reactors as well as, potentially, breeder reactors. The present permitted level of $460 \mathrm{~kg}$ of plutonium at the plant at onc time still allows for several tonnes of plutonium to pass through the plant each year.

Coming as it does just weeks before the 5 April state clcctions in Hesse, the plutonium dispute has provided fertile political ground for candidates of all parties, including Wallmann himsclf, who is running for the conservative Christian Democrats. Most striking among the partics positions is that of the Social Democrats (SPD), who have done an about-face on the issue of nuclear power in the past two ycars, swinging from a pro-nuclear position to favouring the abandonment of nuclear power in West Germany over the next ten years.

In this, however, they are not as extreme as their coalition partners in Hesse, the Greens, who demand an immediate shutdown of the German nuclear industry. In fact, the so-called "redgreen" coalition in Hesse was dissolved in February over the licensing of Alkem.

The contamination of at least 14 workers with plutonium at Alkem's sister company Nukem in Fcbruary has added to the uproar. But as the fuel containers are said not to have been opened since their manufacture in 1970 , it seems unlikely that Nukem will ultimately be blamed for the accident.

The lcader of the SPD in Hesse. Ernst Weltekc, admitted that the Hessian government's Supreme Court case will probably not get very far. At best, he said, the case may force the Bundestag (the federal parliament) to face the issue of the plutonium industry.

Steven Dickman 